\title{
Ellis-Van Creveld Syndrome
}

National Cancer Institute

\section{Source}

National Cancer Institute. Ellis-Van Creveld Syndrome. NCI Thesaurus. Code C84684.

A rare autosomal recessive syndrome caused by mutations in the EVC gene. It is characterized by dwarfism, small chest, ectodermal dysplasia, and postaxial polydactyly. There is an increased frequency of cong enital heart malformations. 